\title{
PERBANDINGAN HASIL BELAJAR FISIKA SISWA YANG MENGGUNAKAN METODE PEMBELAJARAN STUDENT FACILITATOR AND EXPLAIN (SFAE) DAN STUDENT TEAMS ACHIEVEMENT DIVISSION (STAD)
}

\author{
Imas Ratna Ermawati \\ A.Kusdiwelirawan \\ Khusnul \\ Program Studi Pendidikan Fisika, Fakultas Keguruan dan Ilmu Pendidikan \\ Universitas Muhammadiyah Prof. Dr. Hamka \\ Email : iye212@yahoo.com
}

\begin{abstract}
Abstrak
Penelitian ini bertujuan untuk mengetahui terdapat atau tidaknya perbandingan hasil belajar fisika siswa antara Metode Student Facilitator And Explain (SFAE) dengan Student Teams Achievement Divission (STAD). Dimana metode yang digunakan dalam penelitian ini adalah metode Quasi eksperimen. Metode pembelajaran Student Facilitator And Explain dan Student Teams Achievement Divission merupakan metode yang melibatkan siswa untuk berperan aktif dalam proses pembelajaran, menjadikan siswa sebagai fasilitator dan berfikir kreatif sehingga dapat menimbulkan rasa percaya diri dan tanggung jawab pada diri siswa. Yang membedakan Metode pembelajaran Student Facilitator And Explain dan Student Teams Achievement Divission adalah langkah-langkah pembelajarannya dimana Metode pembelajaran Student Facilitator And Explain siswa yang belajar sepenuhnya sendiri tidak demikian dengan metode Student Teams Achievement Divission dan di metode Student Teams Achievement Divission diadakan kuis di setiap akhir pertemuannya. Hasil analisis data penelitian ini mengungkapkan, bahwa dari perhitungan hasil belajar fisika siswa pada pokok bahasan Teori Kinetik Gas dan Termodinamika yang diterapkan di kelas eksperimen I dengan metode Student Facilitator And Explain memiliki nilai rata-rata 79,58 sedangkan kelas eksperimen II dengan metode Student Teams Achievement Divission memiliki nilai rata-rata 72,68, yaitu di atas KKM sebesar 70,00. Dari hasil pengujian hipotesis dengan menggunakan uji$\mathrm{t}$ didapat $\mathrm{t}_{\text {hitung }}=3,102>1,667=\mathrm{t}_{\text {tabel. }}$. Hal ini berarti tolak $\mathrm{H}_{0}$, maka hasil penelitian ini menyimpulkan bahwa terdapat perbandingan hasil belajar fisika siswa yang menggunakan metode pembelajaran Student Facilitator And Explain dan Student Teams Achievement Divission.
\end{abstract}

Kata Kunci : Metode Pembelajaran Student Facilitator And Explain, Metode Student Teams Achievement Divission. 
Imas Ratna Ermawati - Perbandingan Hasil Belajar ...

\section{PENDAHULUAN}

Manusia sebagai makhluk yang dibekali akal dan pikiran. Memiliki kemampuan untuk terus meningkatkan potensi diri agar dapat menjadi pribadi yang lebih baik lagi dari sebelumnya. Oleh karena itu manusia membutuhkan pendidikan dalam kehidupannya. Pendidikan merupakan usaha agar manusia dapat mengembangkan potensi dirinya melalui proses pembelajaran dan cara lain yang dikenal dan diakui oleh masyarakat. Pendidikan berlangsung secara sistematis melalui tahapantahapan.

Dalam penyelenggaraan pendidikan di sekolah yang melibatkan guru sebagai pendidik dan siswa sebagai peserta didik, diwujudkan dengan adanya interaksi belajar mengajar atau proses belajar mengajar. Dimana dalam proses belajar mengajar dibutuhkan metode pembelajaran yang kreatif dan inovatif agar proses belajar mengajar menjadi menyenangkan dan tidak membosankan. Sehingga, diharapkan siswa mendapatkan nilai yang maksimal.

Metode pembelajaran yang bervariasi dan menarik minat peserta didik harus dikuasai guru. Dari berbagai macam metodepembelajaran yang ada terdapat metode pembelajaran yang dapat menarik siswa sehingga siswa merasa senang mengikuti proses belajar mengajar di dalam kelas dimana guru dapat memberikan kesempatan kepada siswa untuk ikut serta dalam kegiatan belajar mengajar. Metode pembelajaran yang dimaksud adalah metode pembelajaran Student Facilitator And Explain (SFAE) dan Student Teams Achievement Divissions (STAD).

Sedangkan,metode pembelajaran Student Teams Achievement Divission (STAD) didasarkan pada prinsip, siswa bekerja bersama-sama dalam belajar dan bertanggung jawab terhadap belajar dalam tim dan dirinya sendiri. Dimulai dari guru menyajikan pelajaran. Kemudian guru lebih menekankan peserta didik dalam belajar bersama dengan timnya. Salah satu mata pelajaran yang dapat menggunakan metode pembelajaran 
Imas Ratna Ermawati - Perbandingan Hasil Belajar ...

di atas dalam proses belajar mengajarnya adalah fisika. Fisika merupakan ilmu yang lebih banyak memerlukan pemahaman daripada hafalan. Siswa dituntut untuk lebih memahami fisika secara konsep. Oleh karena itu, pada umumnya pelajaran fisika merupakan salah satu pelajaran yang dianggap sulit dan tidak disukai oleh peserta didik.

Seorang siswa dikatakan telah belajar fisika apabila pada diri siswa tersebut terjadi perubahan kognitif, afektif, dan psikomotorik sesuai dengan taksonomi Bloom. Hasil belajar merupakan suatu bentuk perubahan tingkah laku, pengetahuan yang dicapai siswa setelah melakukan proses belajar fisika. Fisika mempelajari tentang fenomena alam yang sangat dekat dengan kehidupan kita sehari-hari.

Siswa sudah mulai terbiasa berfikir kritis mengenai konsep yang terjadi pada alam ini melalui pembelajaran fisika. Salah satu tujuan untuk mencapai hasil belajar fisika yang baik melihat dari tes penguasaan materi yang diberikan oleh guru pada siswa dalam bentuk nilai. Untuk mencapai hasil belajar yang maksimal tentu harus didukung dengan proses pembelajaran yang baik. Mulai dari sarana dan prasarana, metode yang digunakan guru, hingga kemampuan dari siswa sendiri dalam menyerap informasi.

Selain itu perlu adanya motivasi dalam diri siswa untuk belajar fisika agar mendapatkan hasil belajar yang diinginkan. Hasil belajar mempunyai peran penting dalam proses pembelajaran. Bagi guru untuk melihat hasil belajar siswa dilihat dari tingkat perkembangan pengetahuan siswa.. Proses penilaian terhadap hasil belajar ditujukan agar guru mendapatkan informasi tentang kemajuan siswa sebagai upaya tujuantujuan pembelajaran dapat dicapai melalui kegiatan belajar. Selanjutnya dari informasi tersebut guru dapat menyusun dan membina kegiatankegiatan siswa lebih lanjut, baik untuk keseluruhan kelas maupun individu

Metode pembelajaran Student Facilitator and Explain dengan langkah-langkah pembelajaran seperti itu diharapkan, metode pembelajaran Student Facilitator and Explain dapat 
Imas Ratna Ermawati - Perbandingan Hasil Belajar ...

meningkatkan hasil belajar fisika

siswa, karena siswa terlibat secara langsung dalam proses pembelajaran.

Siswa diberikan kesempatan untuk mempresentasikan ide atau pendapat mereka pada rekan lainnya. Menjadikan siswa sebagai fasilitator dan di ajak berfikir secara kreatif sehingga menghasilkan pertukaran informasi lebih mendalam dan lebih menarik serta menimbulkan rasa percaya diri dan tanggung jawab pada diri siswa.

Metode pembelajaran Student Teams Achievement Divission merupakan metode sederhana dan langsung dari pendekatan pembelajaran kooperatif tipe STAD.

Dalam menyajikan informasi guru harus menimbulkan minat siswa dan menarik perhatiannya, sehingga siswa dapat menerima pelajaran dengan penuh perhatian. Guru berperan sebagai motivator mereka saat pembelajaran berlangsung. Siswa akan merasa nyaman belajar dengan didukung oleh lingkungan kelas yang kondusif dan metode pembelajaran yang sesuai dengan kebutuhan mereka. Sehingga, siswa akan termotivasi untuk belajar dengan senang hati tanpa adanya paksaan.

\section{METODE}

Tujuan penelitian ini adalah untuk mengetahui apakah terdapat perbandingan hasil belajar fisika siswa yang menggunakan metode pembelajaran Student Facilitator And Explain (SFAE) dengan metode pembelajaran Student Team Achievement Divissions (STAD) di SMA Negeri 105 Jakarta.

Penelitian ini dilaksanakan di SMA Negeri 105 Jakarta. Dengan alamat Jln. Usman Kelurahan Kelapa Dua Wetan, Ciracas, Jakarta Timur.

Untuk memperoleh data yang dibutuhkan dalam penelitian ini, peneliti menggunakan metode penelitian kuantitatif. Penelitian yang akan digunakan dalam penelitian ini adalah penelitian eksperimen. Desain penelitian yang digunakan adalah Quasi eksperimen .

Dalam penelitian ini, ada dua kelompok. Kelompok pertama adalah kelompok perlakuan (Eksperimen I), yaitu kelas yang diberikan metode pembelajaran Student Facilitator And 
Imas Ratna Ermawati - Perbandingan Hasil Belajar ...

Explain (SFAE), dan kelompok kedua adalah kelompok perlakuan (Eksperimen II), yaitu kelas yang diberikan metode pembelajaran Student Teams Achievement

Divission (STAD).

Desain

penelitian

ini menggunakan desain pretest-posttest. Tes dilakukan sebanyak dua kali yaitu pretest yang diambil sebelum mendapatkan perlakuan dalam bentuk 44 soal pilihan ganda dan posttest yang diambil setelah siswa Mendapatkan perlakuan dalam bentuk 44 soal pilihan ganda.

Untuk dapat mengetahui hasil belajar siswa, data diperoleh berasal dari hasil belajar pokok bahasan. Teori Kinetik Gas dan Termodinamika.

\section{HASIL DAN PEMBAHASAN}

Dalam penelitian ini, data hasil belajar fisika diperoleh dari penyebaran instrumen berupa tes pada responden di kelas eksperimen. Penyebaran instrumen tes dilakukan setelah sampel diberi perlakuan berupa pembelajaran dengan metode pembelajaran Student Facilitator And Explain (SFAE) dan Student Teams Achievement Divission (STAD) sebanyak 6 kali pertemuan pada pokok bahasan Teori Kinetik Gas dan Termodinamika.

Berdasarkan rekapitulasi data hasil belajar fisika yang diperoleh dari kelas eksperimen I berjumlah 40 sampel, di dapatkan data tertinggi yaitu 95 dan terendah yaitu 55 dengan nilai rata-rata 79,58. Sedangkan, kelas eksperimen II berjumlah 40 sampel, di dapatkan data tertinggi yaitu 89 dan terendah yaitu 50 dengan nilai ratarata 72,68 .

Sebelum melakukan pengujian hipotesis, terlebih dahulu dilakukan pengujian normalitas dan homogenitas. Pengujian normalitas yang dilakukan dengan menggunakan rumus Chi Kuadrat. Pada kelas eksperimen I diperoleh $\chi^{2}=3,78$, sedangkan kelas eksperimen II

diperoleh $\chi^{2}=2,46$. Dari kedua data tersebut dapat disimpulkan bahwa data berdistribusi Normal. Selanjutnya, dilakukan pengujian Homogenitas dengan menggunakan Uji Fisher. Hasil uji homogenitas 
Imas Ratna Ermawati - Perbandingan Hasil Belajar ...

diperoleh $F_{\text {hitung }}=1,021$. Karena $\mathrm{F}_{\text {hitung }}=1,021<1,705=\mathrm{F}_{\text {tabel }}$, maka dapat disimpulkan bahwa sampel kedua kelas yaitu kelas eksperimen I dan kelas eksperimen II mempunyai kondisi yang homogen.

Diperoleh $t_{\text {hitung }}$ sebesar 3,102 sedangkan dk 78 dan taraf signifikansi $\alpha=0,05$ bila di cocokan dengan harga t tabel 1,667. Karena $t_{\text {hitung }}=3,102>$ $1,667=\mathrm{t}_{\text {tabel }}$ maka dapat dinyatakan bahwa terdapat perbandingan hasil belajar fisika siswa yang diterapkan metode Student Facilitator And Explain (SFAE) dengan metode Student Teams Achievement Divission (STAD).

\section{PENUTUP}

\section{Kesimpulan}

Berdasarkan hasil penelitian dapat disimpulkan bahwa dalam pembelajaran dengan menggunakan metode pembelajaran Student Facilitator And Explain (SFAE) sebagai metode pembelajaran yang dapat menarik minat dan perhatian siswa karena dalam metode ini siswa akan lebih aktif dan kreatif dalam berfikir. Siswa diberikan kesampatan untuk saling bekerja sama dalam setiap kelompoknya. Karena di dalam pembelajaran siswa dituntut berperan aktif sebagai fasilitator bagi siswa yang lainnya. Siswa yang satu saling mengajarkan siswa yang lain dalam kelompok. Sehingga kemampuan yang dimiliki setiap kelompok akan sama, masing-masing siswa akan memahami materi yang dipelajarinya. Sedangkan, penggunaan metode pembelajaran Student Team Achievement Divission (STAD) sebagai metode pembelajaran yang menuntut siswa untuk bekerja sama dalam kelompoknya. Dalam kegiatan kelompok siswa tetap berperan sebagai fasilitator bagi siswa lainnya, sehingga siswa menjadi termotivasi untuk menerima pelajaran. Adanya kuis di akhir pembelajaran membuat siswa lebih termotivasi untuk belajar sehingga kemampuan siswa yang satu dengan yang lainnya sama.

Rata-rata hasil penelitian hasil belajar fisika siswa yang diterapkan metode Student Facilitator And Explain (SFAE) lebih tinggi dari pada hasil belajar fisika siswa yang 
Imas Ratna Ermawati - Perbandingan Hasil Belajar ...

diterapkan metode Student Teams

Achievement Divission (STAD).

Hal ini menunjukkan bahwa dengan diterapkannya metode Student Facilitator And Explain (SFAE) menjadikan siswa semakin aktif dan bekerja sama dalam kegiatan pembelajaran serta memperoleh evaluasi yang berfungsi mengukur tingkat pemahaman dan penguasaan pada materi-materi yang diperoleh.

Dari hasil pengujian dengan menggunakan uji-t dengan taraf nyata $0,05, \mathrm{t}_{\text {hitung }}=3,102>1,667=$ $\mathrm{t}_{\text {tabel. }}$ Maka dapat disimpulkan bahwa terdapat perbandingan hasil belajar fisika siswa yang diterapkan metode Student Facilitator And Explain (SFAE)dengan Student Teams

Achievement Divission (STAD).

\section{DAFTAR PUSTAKA}

Purwanto, Ngalim. 2010, Psikologi Pendidikan.Bandung:PT Remaja Rosdakarya

Suprijono, Agus. 2013. Cooperative Learning Teori \& Aplikasi PAIKEM. Yogyakarta:Pustaka Pelajar

Asmawati R. 2011. Pengaruh Pembelajaran Kooperatif Tipe
STAD Terhadap Penguasaan Konsep Siswa Pada Materi Bunyi. Jakarta: Universitas Islam Negeri

Dimyati Mudjiono .2009. Belajar dan Pembelajaran.Jakarta:PT Rineka Cipta.

Aqib, Zainal. 2013. Modelmodel,Media, dan Strategi Pembelajaran Konstektual (Inovatif). Bandung:Yrama Widya.

Arikunto, Suharsimi, 2012. Dasar dasar Evaluasi Pendidikan(Edisi 2). Jakarta: Bumi Aksara.

Asmani , Jamal Ma'mur. 2012. 7 Tips Aplikasi PAKEM. Yogyakarta: Diva Press.

Halliday, Resnick, \& Walker. 2013. Dasar - Dasar Fisika Jilid 